\title{
Plasmid effects on secondary metabolite production by a streptomycete synthesizing an anthelmintic macrolide
}

\author{
D. Ian Thomas, ${ }^{1 *}$ Jonathan H. Cove,${ }^{1}$ Simon Baumberg,${ }^{2}$ Carol A. Jones ${ }^{3}$ and \\ BRIAN A. M. RUDD ${ }^{3}$ \\ ${ }^{1,2}$ Departments of Microbiology ${ }^{1}$ and Genetics ${ }^{2}$, University of Leeds, Leeds LS2 9JT, UK \\ ${ }^{3}$ Glaxo Group Research Ltd, Greenford Road, Greenford, UB6 OHE, UK
}

(Received 18 April 1991; revised 2 July 1991; accepted 17 July 1991)

\begin{abstract}
Transformation of the thermotolerant streptomycete, soil isolate S541, with plasmid cloning vectors of varying size, copy number, and parent replicon (derived from pIJ101, SCP2* and SLP1.2) depressed the biosynthesis of nemadectins (polyketide-derived secondary metabolites possessing anthelmintic activity). However, production of the chemically distinct 21-hydroxyl-oligomycin A, also produced by S541, was either unaffected or increased in plasmid-containing strains. A causal relationship between plasmid carriage and the changes in secondary metabolite yield was confirmed since cured strains were restored to normal production levels and their subsequent retransformation by plasmid DNA was followed by the same effects on nemadectin and oligomycin biosynthesis as before. All the plasmids tested were highly unstable in S541 and it was generally necessary to include an appropriate selective antibiotic (usually thiostrepton) in the growth medium. Thiostrepton was not responsible for the depressive effect, since this was also observed in plasmid-containing strains (i) when grown in antibiotic-free media and (ii) when alternative selective antibiotics such as neomycin were used. In addition, the plasmid-free strain produced both nemadectins and 21-hydroxyl-oligomycin $A$ in the presence of sub-inhibitory levels of thiostrepton. The thiostrepton resistance gene, which was present on many of the plasmids tested, did not mediate the effect since plasmids carrying other selectable markers (pIJ58, neomycin, and pIJ355, viomycin) also depressed nemadectin but not 21-hydroxyl-oligomycin A production. No obvious recombination or integration events between S541 chromosomal DNA and any of the plasmids tested were revealed by DNA-DNA Southern hybridization.
\end{abstract}

\section{Introduction}

Polyketide-derived compounds with anthelmintic activity are of considerable importance in human and veterinary medicine. Semi-synthetic derivatives of the naturally occurring avermectins are already widely used for the treatment of parasitic infections of domestic livestock (Campbell et al., 1983). Furthermore, these compounds, which are active against Onchocerca volvulus, have potential application in the treatment of onchocerciasis (river blindness) in humans (White et al., 1987).

A number of chemically related endectocides have been isolated from methanol extracts of the mycelium of a thermotolerant streptomycete soil isolate, S541. This was provisionally named Streptomyces thermoarchaensis NCIB 12015 (Ward et al., 1984; Ramsey et al., 1987) but since this name has not been confirmed the isolate is referred to here as $\mathbf{S 5 4 1 . ~ T h e ~ f o u r ~ m a j o r ~ e n d e c t o c i d e s ~}$ were originally designated archaemycins $1-4$ but have been independently reported from another Streptomyces species, Streptomyces cyaneogriseus subsp. noncyanogenus, and the compounds referred to as LL-F28249 compounds, or nemadectins (Carter et al., 1988). The structures of the major nemadectins (the term used henceforth) are shown in Fig. 1(a). These compounds are structurally related to the anthelmintic avermectins and milbemycins but do not possess the oleandrose disaccharide side-chain of the avermectins (Davies \& Green, 1986). Chemical modifications of the nemadectins have given rise to novel compounds, also with potent anthelmintic activity (Ramsay et al., 1987; Beddall et al., 1988). Studies on the chemistry and biosynthesis of nemadectins have suggested that they are products of a condensation reaction between seven acetate and six propionate units together with a 'primer' unit of varying size. Synthesis of the macrolide ring may be catalysed by a single polyketide synthase which can utilize any of the 
(a)

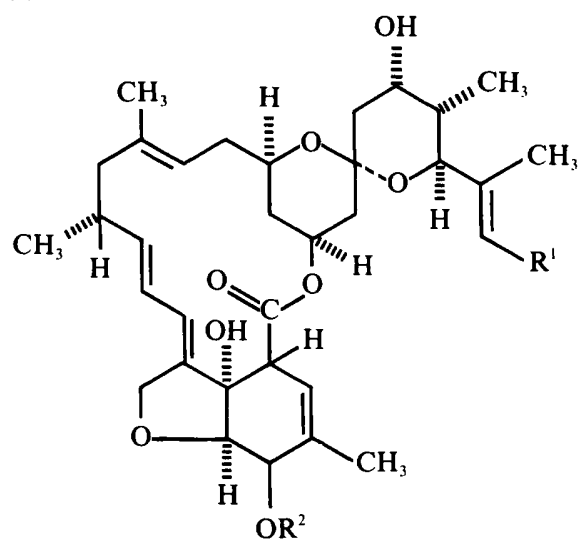

(b)<smiles>CCC(/C=C/C=C/CC(C)C(O)C(C)(O)C(=O)C(C)C(O)C(C)CC(C)C(O)C(C)/C=C/C(=O)OC1C(C)C(CC(O)C(C)CC(C)O)OC2(CCC(C)C(CC(C)O)O2)C1C)C(C)C(O)C(C)CC(C)C</smiles>

Fig. 1. (a) Structures of the major nemadectins produced by S541. Nemadectins 3, 1,2 and 4 are, respectively, compounds LL-F28249 $\alpha, \beta, \lambda$, and $\gamma$ (Carter et al., 1988). $\mathbf{R}^{1}=\mathrm{CH}_{3}$ for nemadectin factors 1 and 4 , $\mathrm{C}_{2} \mathrm{H}_{5}$ for factor 2 and $\left(\mathrm{CH}_{3}\right) \mathrm{CH}$ for factor 3 . $\mathbf{R}^{2}=\mathrm{H}$ for factors 1,2 and 3 , and $\mathrm{CH}_{3}$ for factor 4. (b) Structure of 21-hydroxyl-oligomycin $\mathbf{A}$. primers, acetate, propionate or isobutyrate, to yield the three major products, nemadectin 1,2 and 3, respectively (B. A. M. Rudd, unpublished results). Here there appears to be a clear similarity to the reported biosynthetic origins of the carbon skeleton of the milbemycins (Ono et al., 1983).

In common with other known endectocide producers (e.g. Onishi \& Miller, 1985), S541 was also found to produce an oligomycin antibiotic, identified as 21-hydroxyl-oligomycin A (structure shown in Fig. $1 b$ ). This compound appeared to be synthesized via a separate pathway from that of the nemadectins (B. A. M. Rudd, unpublished results). In addition, S541 produced a green pigment of unknown structure.

The application of recombinant DNA cloning techniques in order to isolate antibiotic biosynthesis genes (Jones \& Hopwood, 1984; Malpartida \& Hopwood, 1984), generate hybrid antibiotics (Hopwood et al., $1985 b$; Omura et al., 1986), isolate regulatory genes and investigate the molecular biology of differentiation (Piret $\&$ Chater, 1985) is well documented (for a review, see Hunter \& Baumberg, 1989). Many instances of cloning antibiotic biosynthesis genes have depended on the complementation of non-producing mutants by genes cloned into plasmid vectors (Bailey et al., 1984; Fishman et al., 1987). However, two complications were encountered when this approach was applied to gene cloning experiments involving S541. Firstly, transformation of the strain with plasmid cloning vectors caused reduction of nemadectin synthesis, and secondly, the plasmids were extremely unstable (C. A. Jones, unpublished results). These factors were major obstacles to the use of recombinant DNA techniques in S541. It was also noted (C. A. Jones, unpublished results) that the S541 transformants carrying plasmid vectors showed increased oligomycin production, while formation of the green pigment was depressed similarly to that of nemadectins.

Here we describe the effects of plasmids of different size, copy number and parent replicon on secondary metabolite production by S541. In order to ascertain whether a causal relationship exists between plasmid carriage and these effects, secondary metabolite production was examined in both cured strains and strains cured and then subsequently retransformed with plasmid DNA. The effects of the antibiotics used to stably maintain the plasmids in S541 cultures were also investigated.

\section{Methods}

Bacterial strains and plasmids. Plasmids used in this study are listed in Table 1. S541 (NCIB 12015) was obtained from Glaxo Group Research Ltd. Streptomyces lividans TK 21 and all plasmids listed in Table 1 were obtained from the John Innes Institute, Norwich, UK. Spore suspensions of streptomycete strains (approximately $10^{8}$ spores $\mathrm{ml}^{-1}$ ) were stored at $-20{ }^{\circ} \mathrm{C}$ in $20 \%(\mathrm{v} / \mathrm{v})$ glycerol/phosphate-buffered saline (PBS), $\mathrm{pH} 7 \cdot 4$. The spores were harvested as described by Hopwood $e t$ al. $(1985 a)$.

Media and growth conditions. S. lividans TK21 spores were produced as described by Hopwood et al. (1985a). S541 sporulated after 7-8 d gi jwth at $30^{\circ} \mathrm{C}$ on a solid medium (TO) containing ( $\left.\mathrm{g} \mathrm{l}^{-1}\right)$ Milupa oat breakfast cereal (Boots), 20; tomato purée (Sainsburys), 20; yeast extract, 10, and agar, 20. The initial $\mathrm{pH}$ was 7.0 .

Cc nplex liquid medium (CLM) contained ( $\left.\mathrm{g}^{-1}\right)$ glucose, 2.5; malt dextrin (Roquette Frere), 25; Arkasoy (British Arkady), 12.5; molasses, $1.5 ; \mathrm{K}_{2} \mathrm{HPO}_{4}, 0.125 ; \mathrm{CaCO}_{3}, 1.25 ; \mathrm{MOPS}, 21$, and was adjusted to $\mathrm{pH} 7.0$ prior to autoclaving.

Chemically defined medium (DLM) contained $\left(\mathrm{g}^{-1}\right) \mathrm{NH}_{4} \mathrm{Cl}, 2 \cdot 45$; $\mathrm{MgSO}_{4} \cdot 7 \mathrm{H}_{2} \mathrm{O}, 0 \cdot 22 ; \mathrm{CaCl}_{2} .2 \mathrm{H}_{2} \mathrm{O}, 0 \cdot 168 ; \mathrm{MOPS}, 38$, and was adjusted to $\mathrm{pH} 8.0$ prior to autoclaving. Filter-sterilized supplements were then added to give final quantities of $\left(1^{-1}\right)$, glucose $41 \mathrm{~g} ; \mathrm{K}_{2} \mathrm{HPO}_{4}, 0.47 \mathrm{~g}$; $\mathrm{ZnSO}_{4} .7 \mathrm{H}_{2} \mathrm{O}, 6.5 \mathrm{mg} ; \mathrm{FeCl}_{3} .6 \mathrm{H}_{2} \mathrm{O}, 2.9 \mathrm{mg} ; \mathrm{CuCl}_{2} .2 \mathrm{H}_{2} \mathrm{O}, 77 \mu \mathrm{g}$; $\mathrm{CoCl}_{2} \cdot 6 \mathrm{H}_{2} \mathrm{O}, 110 \mu \mathrm{g}$. 
Table 1. Plasmids used in this study

\begin{tabular}{|c|c|c|c|c|}
\hline Parent replicon & Vector & $\begin{array}{l}\text { Size } \\
(\mathbf{k b})\end{array}$ & Markers* & Reference \\
\hline pIJ101 (high copy no.: 40-300) & $\begin{array}{l}\text { pIJ58 } \\
\text { pIJ355 } \\
\text { pIJ365 } \\
\text { pIJ702 }\end{array}$ & $\begin{array}{r}3 \cdot 3 \\
10 \cdot 8 \\
5 \cdot 4 \\
5 \cdot 8\end{array}$ & $\begin{array}{l}\text { aph } \\
\text { vph, Ltz }{ }^{+} / \\
t s r, \text { aph } \\
t s r, \text { mel }\end{array}$ & $\begin{array}{l}\text { Kieser et al. (1982) } \\
\text { Katz et al. (1983) }\end{array}$ \\
\hline SCP2* (low copy no.: 1-2) & $\begin{array}{l}\text { pIJ922 } \\
\text { pIJ941 }\end{array}$ & $\begin{array}{l}24 \cdot 0 \\
25 \cdot 0\end{array}$ & $\begin{array}{l}\text { tsr, } \mathrm{Ltz}^{+} \\
\text {tsr, hyg, } \mathrm{Ltz}^{+}\end{array}$ & Lydiate et al. (1985) \\
\hline SLP1.2 (low copy no.: 4-5) & pIJ61 & 14.8 & $t s r, a p h, \mathrm{Ltz}^{+}$ & Thompson et al. (1982a) \\
\hline
\end{tabular}

* aph, aminoglycoside (neomycin) phosphotransferase; hyg, aminoglycoside (hygromycin) phosphotransferase; tsr, thiostrepton resistance; mel, tyrosinase gene; $v p h$, aminoglycoside (viomycin) phosphotransferase; Ltz, pocking phenotype.

\begin{abstract}
Unless stated otherwise, thiostrepton $\left(25 \mu \mathrm{g} \mathrm{ml}^{-1}\right)$ was included in culture media for the growth of plasmid-containing strains.

Inocula of S541 were prepared by the addition of $200 \mu 1$ spore suspension to $25 \mathrm{ml} \mathrm{CLM} \mathrm{in} 250 \mathrm{ml}$ Erlenmeyer flasks and incubated at $31^{\circ} \mathrm{C}$ for $48 \mathrm{~h}$ on an orbital shaker at 250 r.p.m. One ml of culture was used to inoculate $37 \mathrm{ml}$ DLM in Erlenmeyer flasks for shake flask cultures and $100 \mu \mathrm{l}$ used to inoculate $2.5 \mathrm{ml} \mathrm{CLM}$ in $50 \mathrm{ml}$ boiling tubes for shake tube cultures. Both flasks and tubes were incubated under the same conditions as the inoculum. S541 was also grown in stirred batch cultures using a 2-litre LH500 Series fermenter equipped with baffles and containing $1800 \mathrm{ml}$ DLM. The temperature was maintained at $31{ }^{\circ} \mathrm{C}$ and the $\mathrm{pH}$ at $6 \cdot 6-7 \cdot 2$ by the addition of $3 \%(\mathrm{v} / \mathrm{v}) \mathrm{H}_{2} \mathrm{SO}_{4}$ and $6 \%$ (w/v) $\mathrm{NaOH}$. The air flow was $1.01 \mathrm{~min}^{-1}$ and the culture was stirred at 700 r.p.m., which maintained the dissolved oxygen concentration at $\geqslant 40 \%$ air saturation. Antifoam (polypropylene glycol 2000) was added as required. A $1 \%(\mathrm{v} / \mathrm{v})$ inoculum was used. Samples $(5 \mathrm{ml})$ were removed for analysis at $24 \mathrm{~h}$ intervals throughout the $7 \mathrm{~d}$ period of growth.
\end{abstract}

Estimation of biomass. Culture samples $(2 \mathrm{ml})$ were centrifuged at $5000 \mathrm{~g}$ for $10 \mathrm{~min}$ and the cell pellet washed with distilled water, centrifuged, resuspended in $10 \mathrm{ml}$ distilled water and filtered through a pre-weighed cellulose acetate membrane filter, pore size $0.45 \mu \mathrm{m}$ (Oxoid) and dried at $110^{\circ} \mathrm{C}$.

Semiquantitative estimation of plasmid content. Mycelial aggregation in the samples was reduced by treating $1.0 \mathrm{ml}$ culture in an ultrasonic water bath (Kerry Ultrasonics) for $30 \mathrm{~s}$ followed by $2.0 \mathrm{~min}$ agitation by vortexing. The suspension was diluted in $20 \%(\mathrm{v} / \mathrm{v})$ glycerol/PBS and plated onto TO agar both with and without an appropriate selective antibiotic. Plasmid carriage (\%) was estimated by comparing the counts on the two media:

Estimation of nemadectins and 21-hydroxyl-oligomycin A. Culture samples $(2.0 \mathrm{ml})$ were centrifuged at $10000 \mathrm{~g}$ for $5.0 \mathrm{~min}$ and the cells extracted with 1.8 mil methanol for $1 \mathrm{~h}$ at room temperature. The cells were removed by centrifugation and supernatant fluid analysed using reverse-phase HPLC. The column was a $10 \mathrm{~cm}$ Spherisorb ODS-2 (LKB-Pharmacia) and the mobile phase 65:35 (v/v) acetonitrile/ $0 \cdot 1 \mathrm{M}-\mathrm{NH}_{4} \mathrm{H}_{2} \mathrm{PO}_{4}$, run at $3 \mathrm{ml} \mathrm{min}{ }^{-1}$. The products were identified and quantified using purified standards (provided by Glaxo Group Research Ltd) of known concentration. Nemadectin titres were calculated as the combined totals of factors $1,2,3$ and 4.

Plasmid transformation and DNA manipulation. S. lividans TK21 (Hopwood et al., 1983) was used as the initial host strain for the plasmids listed in Table 1. The media and culture conditions used for growth of S. lividans and S541 were as described by Hopwood $e t$ al. (1985a). Plasmid DNA was isolated by alkaline lysis (Hopwood et al., 1985a) and subsequent caesium chloride/ethidium bromide densitygradient centrifugation (Sambrook et al., 1989).

Plasmid curing. S541 was cured of plasmids during growth on TO agar in the absence of a selective antibiotic and plasmid-free derivatives identified by loss of antibiotic resistance and also by the absence of detectable plasmid DNA in plasmid mini-preps.

Probe preparation and Southern blot hybridizations. These were carried out as described by Vallins \& Baumberg (1985).

\section{Results and Discussion}

\section{Effects of plasmid carriage on antibiotic synthesis}

The nemadectins and 21-hydroxyl-oligomycin A were readily quantified by HPLC analysis of methanol extracts of plasmid-free S541 cells grown in stirred submerged batch culture. The 21-hydroxyl-oligomycin A was initially detected after $2 \mathrm{~d}$ growth and the nemadectins after $3 \mathrm{~d}$ (Fig. $2 a$ ). The level of both these metabolites increased during the phase of biomass increase and subsequently throughout the stationary phase. Transformation of S541 with plasmid DNA caused a severe reduction in the level of nemadectins produced but the level of 21-hydroxyl-oligomycin A was either unchanged or increased (Fig. $2 a, b, c$, Table 2). In order to establish whether there was a direct causal association between plasmid carriage and this effect, the production of nemadectins and 21-hydroxyl-oligomycin A was examined in batch cultures of plasmid-containing S541, derivatives cured of their plasmids and cured derivatives subsequently retransformed with the plasmid they originally carried. The presence or absence of plasmids in S541 was confirmed by the detection of selectable markers and directly by performing plasmid mini-preps. The batch cultures showed clearly that S541 

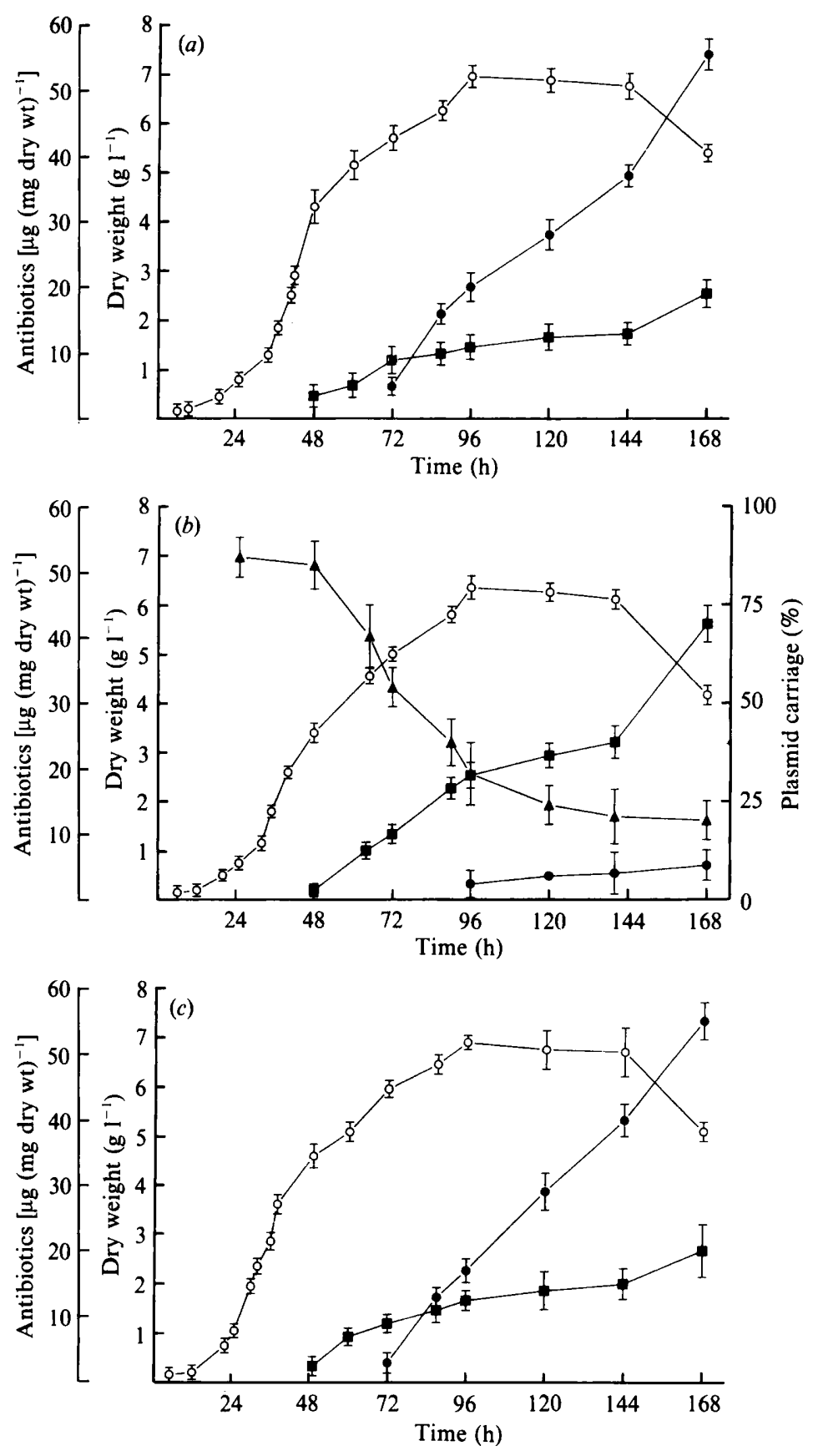

Fig. 2. Growth, plasmid carriage and fermentation products of $\mathrm{S} 541$ grown in batch culture : (a) plasmidfree S541, (b) S541 containing pIJ702 (grown in the presence of $25 \mu \mathrm{g}$ thiostrepton $\mathrm{ml}^{-1}$ ), (c) S541 cured of pIJ702. O, Biomass; $\bullet$, nemadectin; $\mathbf{\square}$, oligomycin; $\Delta$, plasmid carriage. The results represent the data obtained from triplicate experiments. Bars represent standard errors. containing pIJ702 ('ig. $2 b$ ) produced approximately one-tenth the amount of nemadectin and approximately twice the amount of 21-hydroxyl-oligomycin A compared with the plasmid-free untransformed derivative and S541 cured of the plasmid pIJ702 (Fig. 2c). Retransformation of the cured strain with pIJ702 again resulted in severe depression of nemadectin and increase in oligomycin yields. Other plasmids derived from pIJ101, in addition to apparently unrelated plasmids pIJ922, pIJ941 and pIJ61, also exerted similar effects. Table 2 summarizes the results of batch culture experiments in which the maximum levels of nemadectin and 21-hydroxyl-oligomycin A are recorded for the plasmid-containing, cured and retransformed cultures. These results show that the effects on nemadectin and oligomycin yields were specifically plasmid-mediated since the effect was reversed when S541 was cured and recurred on retransformation with plasmid DNA. They therefore preclude the possibility that non-nemadectinproducing variants (e.g. mutants or cells which have lost 
Table 2. Antibiotic production by plasmid-free and plasmidcontaining 5541

Shake flask cultures of S541 transformed with plasmid DNA, derivatives cured of their plasmid, and derivatives subsequently retransformed with the plasmid they originally carried, were assayed for nemadectin (Nema) and 21-hydroxyl-oligomycin A (Oligo) after $7 \mathrm{~d}$ growth. The results represent the data obtained from duplicate experiments.

\begin{tabular}{|c|c|c|c|c|c|c|}
\hline \multirow[b]{3}{*}{ Plasmid* } & \multicolumn{6}{|c|}{ Antibiotic titre $\left[\mu \mathrm{g}(\mathrm{mg} \text { dry } w t)^{-1}\right]$} \\
\hline & \multicolumn{2}{|c|}{$\begin{array}{c}\text { Transformed } \\
\text { S541 }\end{array}$} & \multicolumn{2}{|c|}{$\begin{array}{c}\text { Cured } \\
\text { derivative }\end{array}$} & \multicolumn{2}{|c|}{$\begin{array}{c}\text { Retransformed } \\
\text { derivative }\end{array}$} \\
\hline & Nema & Oligo & Nema & Oligo & Nema & Oligo \\
\hline pIJ702 & $5 \cdot 1$ & 42 & 56 & 20 & $3 \cdot 3$ & 40 \\
\hline pIJ355 & 6.0 & 45 & 68 & 21 & 5.0 & 38 \\
\hline pIJ365 & 0.5 & 36 & 54 & 15 & $7 \cdot 3$ & 44 \\
\hline pIJ58 & $2 \cdot 5$ & 32 & 50 & 12 & 3.5 & 38 \\
\hline pIJ922 & 9.5 & 44 & 64 & 14 & $4 \cdot 2$ & 31 \\
\hline pIJ941 & $4 \cdot 1$ & 48 & 48 & 11 & 1.5 & 33 \\
\hline pIJ61 & 3.5 & 39 & 57 & 18 & $4 \cdot 5$ & 36 \\
\hline \multicolumn{3}{|c|}{$\begin{array}{l}\text { Original untransformed S541 } \\
\text { (included for comparison: } \\
\text { from Fig. } 2 a \text { ) }\end{array}$} & 58 & 19 & & \\
\hline
\end{tabular}

* See Table 1.

indigenous plasmids) were selected by the transformation protocol, for example during protoplasting or the regeneration of protoplasts. They also show that the effect was mediated by both high- and low-copy-number plasmids derived from the three different parent replicons, pIJ101, SLP1.2 and SCP2*. In all cases (both here and described later), changes in production of the unknown green pigment paralleled those in nemadectin production.

\section{Effect of selective antibiotics on antibiotic production}

All the plasmids studied were highly unstable in S541 and plasmid-free strains could be readily obtained simply by plating on to non-antibiotic-containing media. Although selective antibiotics (usually thiostrepton) were included in the DLM used in batch cultures, plasmids were lost rapidly during the stationary phase. This occurred with all the plasmids tested and is shown for pIJ702 in Fig. 2(b). It is therefore possible that the plasmid-mediated depression of nemadectin and increase in oligomycin yields were exerted during an early phase of growth (i.e. the first $2 \mathrm{~d}$ ) and that the residual level of nemadectin detected was a result of biosynthetic activity by the plasmid-free cells within the culture. Although streptomycetes have been shown to possess thiostrepton-inducible promoters (Murakami et al., 1989) several lines of evidence show that the depression of nemadectin production was not mediated by the inclusion of antibiotics in the growth medium used to ensure plasmid stability. Stirred submerged batch cultures revealed that the effect was independent of the antibiotic used and occurred in the presence of thiostrepton (for the selection of pIJ702, pIJ365, pIJ922, pIJ941 and pIJ61), neomycin (for the selection of pIJ58, pIJ365 and pIJ61) and viomycin (for the selection of pIJ355). The effects on secondary metabolite production in cultures of S541 containing pIJ702 were independent of thiostrepton concentration from 0.5 to $50 \mu \mathrm{g} \mathrm{ml}^{-1}$, which is consistent with but does not prove absence of direct effect. More importantly, the addition of subinhibitory concentrations of thiostrepton to cultures of plasmid-free S541 did not elicit the same response as plasmid carriage (i.e. decreased levels of nemadectin and increased levels of 21-hydroxyl-oligomycin A). In shake flask cultures of plasmid-free $\$ 541$ containing a range of thiostrepton concentrations $\left(0-0.25 \mu \mathrm{g} \mathrm{ml}^{-1}\right)$ the level of nemadectin remained in approximately a constant ratio $(3 \cdot 3: 1)$ to the level of 21-hydroxyl-oligomycin A. The minimum inhibitory concentration of thiostrepton for the plasmid-free strain was $0.35 \mu \mathrm{g} \mathrm{ml}^{-1}$.

\section{Effect of plasmid-located determinants on antibiotic production}

It seemed unlikely that the depression of nemadectin and increase in oligomycin production were caused by pleiotropic effects mediated by the plasmid-located antibiotic resistance determinants. The influence of the thiostrepton resistance gene (encoding a ribosomal methylase; Cundliffe, 1978; Thompson et al., 1982b) was however investigated using pIJ365, a plasmid vector with both thiostrepton (tsr) and neomycin $(a p h)$ resistance genes. Insertional inactivation of the $t s r$ gene was achieved by ligating a 400 bp DNA fragment from the staphylococcal plasmid pSK 265 into the ClaI site within the $t s r$ gene of pIJ365, giving rise to the plasmid pUL3001. Comparison between stirred submerged batch cultures of S541 constructs containing pIJ365 and pUL3001 revealed that they were both equally depressed in nemadectin production and stimulated in 21-hydroxyloligomycin A production. The results of both batch cultures were similar in all respects to those obtained for all the other plasmid-containing constructs tested, as illustrated for S541 containing pIJ702 in Fig. 2(b). This finding shows that the effects on secondary metabolite production were not a result of reduced efficiency of translation of nemadectin biosynthesis gene mRNA transcripts by ribosomes containing methylated rRNA. Further evidence for the non-involvement of plasmidlocated antibiotic resistance genes was provided by the observation that all the plasmids mediated the effect although they carried different resistance determinants.

Since antibiotic resistance genes (e.g. tsr, aph, $v p h$ and $h y g$ ) were evidently not responsible for the depression of 
nemadectin production in S541, other plasmid determinants must be implicated. The smallest plasmid identified in this study as mediating the effect was pIJ58. This plasmid comprises the aph gene ligated into a $2 \cdot 1 \mathrm{~kb}$ SacII fragment of the naturally-occurring plasmid pIJ101 (Kieser et al., 1982). The recircularized SacII fragment is the minimal replicon of pIJ101 and is capable of autonomous replication in several Streptomyces species. The resistance determinant is required for maintenance of the plasmid in S541 during growth. Kendall \& Cohen (1988) have reported the entire nucleotide sequence of pIJ101 and have identified within the $2 \cdot 1 \mathrm{~kb}$ SacII fragment two potential open reading frames coding for proteins containing 56 (ORF 56) and 450 (ORF rep) amino acids, as well as a presumed noncoding region which they suggest may represent an origin of replication. A search of the University of Leeds OWL composite sequence database (Akrigg et al., 1988) did not reveal any proteins having significant amino acid sequence homology with either protein, thus confirming and updating the earlier report of Kendall \& Cohen (1988). Nevertheless the depression of nemadectin and increase in oligomycin yields by S541 may be mediated either directly or indirectly by plasmid replication functions via mechanisms unknown. It will therefore be of interest to determine the functions of the two proteins encoded by the $2.1 \mathrm{~kb}$ SacII fragment of pIJ 101 .

A DNA probe comprising a $t s r$ gene fragment was isolated on a 520 bp PvuII-ClaI fragment of pIJ702 and was used to test the possibility that the effects on secondary metabolite production were mediated through integration of plasmid DNA into the $\mathrm{S} 541$ chromosome. DNA-DNA Southern hybridizations were carried out against EcoRV digests of total DNA isolated from S541 constructs containing pIJ365, pIJ702, pIJ922, pIJ941 and pIJ61, all of which possess a single EcoRV site within $t s r$. In all cases the autoradiographs showed a single band of size corresponding to linearized plasmid (results not shown). Integration of even a small proportion of plasmid molecules into the chromosome would have been detectable by the presence of additional bands of unpredictable size, but these were not observed, even with gross overexposure of the autoradiograph. It would appear that the molecular mechanism whereby nemadectin production is depressed and that of oligomycin stimulated in plasmid-containing constructs is not dependent on integration of the plasmid into the S541 chromosome. A similar result, i.e. a single band in the autoradiograph, was obtained when linearized pIJ702 was used to probe total DNA from S541 containing this plasmid, thereby excluding the possibility that use of the tsr probe alone had failed to reveal a double crossover event in a region of pIJ702 external to the resistance gene.

\section{Concluding remarks}

Circumstantial evidence certainly exists to support the view that the plasmid-mediated depression of nemadectin and increase in oligomycin biosynthesis occurs at a regulatory level. S541 produces two different macrolide secondary metabolites and at least one other unidentified product, the green pigment. The two macrolides are synthesized from the same primary metabolites (Bu'Lock et al., 1986; Rudd et al., 1990), i.e. mainly acetate and propionate. The production of nemadectins and the green pigment was suppressed by autonomous plasmids, but that of oligomycin was not (the increase in oligomycin production may be explained by the reduced competition for substrate). Since oligomycin production was not reduced, the suppression of nemadectin biosynthesis cannot be explained by a reduction in the supply of primary precursors and therefore must reflect action at a regulatory step. A specific effect on nemadectin biosynthesis is less likely since the production of green pigment was also reduced (data not shown). Furthermore, it is possible that this plasmid effect operates via a regulatory cascade. There was a reproducible difference in the time course of oligomycin and nemadectin production in batch cultures (see legend of Fig. 2), suggesting that a factor/s in a regulatory sequence or cascade may be the mediator of this effect (with oligomycin production being controlled by factors or steps acting earlier in the sequence and unimpaired, or perhaps even potentiated, by the plasmid effect). Further elucidation of this system may therefore give rise to valuable information on the identity of steps in the regulatory cascades of Streptomyces.

It would of course be of great interest to investigate directly whether depression of nemadectin and increase in oligomycin production result from changes in availability of primary metabolite precursors, or from, for example, changes in levels of the corresponding biosynthetic enzymes; and if the latter, whether all enzymes in each pathway are affected similarly or not. An indication that at least some late stages of nemadectin synthesis occur normally in S541 transformed with pIJ702, is that bioconversion of factor $\mathrm{L}$, a precursor of nemadectin 3, to nemadectin 3 in cultures of this strain was similar to that in cultures of plasmid-free S541 (data not shown). However, in the absence of information on actual enzyme levels, it remains possible that the apparent similarity in precursor utilization masks lowered enzyme activity in the plasmid-carrying culture.

Apart from several anecdotal reports, there have been few documented examples of plasmid-mediated depression or stimulation of secondary metabolite production. The plasmid pIJ702 has however been reported, without details, to depress streptomycin production by 
Streptomyces griseus (Vallins \& Baumberg, 1985). A similar depressive effect on tylosin production by Streptomyces fradiae constructs mediated by the plasmids pIJ702 and pIJ922 and the integrated vector pKC796 has also been reported (Cox \& Seno, 1990). It is therefore quite possible that the plasmid effects on the nemadectin/oligomycin/S541 system reported here represent an extreme example of a much more widespread phenomenon than is generally supposed.

It is tempting to consider whether stimulatory effects of plasmid carriage as on oligomycin production here, could be turned to advantage in enhancing yields of useful secondary metabolites.

We thank D. A. Hopwood and T. E. Kieser for plasmids. D.I.T. acknowledges an SERC CASE research studentship.

\section{References}

Akrigg, D., Bleasby, A. J., DiX, N. I. M., Findlay, J. B. C., North, A. C. T., Parry-Smith, D., Wootton, J. C., Blundell, T. L., Gardner, S. P., Hayes, F., Islam, S., Sterneerg, M. J. E., Thornton, J. M., TICKLe, I. J. \& MURRAY-Rust, P. (1988). A protein sequence/structure database. Nature, London 335, 745-746.

Bailey, C. R., Butler, M. J., Normansell, I. D., Rowlands, R. T. \& Winstanley, D. J. (1984). Cloning a Streptomyces clavuligerus genetic locus involved in clavulanic acid biosynthesis. Bio/Technology 2, 808-811.

Beddall, N. E., Howes, P. D., Ramsay, V. J., Roberts, M., Slawin, A. M. Z., Sutherland, D. R., Tiley, E. P. \& Williams, D. J. (1988). Chemical transformations of S541 factors (A)-(D): preparation and reactions of the 23-ketones. Tetrahedron Letters 29, 2595-2598.

Bu'Lock, J. D., Morris, G. A. \& Richards, M. K. (1986). Biosynthetic origins of the large macrolide, oligomycin A. Tetrahedron Letters 27, 2917-2920.

CAMPbell, W. C., Fisher, M. H., Stapley, E. O., Albers-SchöNberg, G. \& JACOB, T. A. (1983). Ivermectin: a potent new antiparasitic agent. Science 221, 823-828.

Carter, G. T., Nietsche, J. A., Hertz, M. R., Williams, D. R., Siegel, M. M., Morton, G. O., James, J. C. \& Borders, D. B. (1988). LL-F28249 antibiotic complex : a new family of antiparasitic macrocyclic lactones. Isolation, characterization and structures of LL-F28249 $\alpha, \beta, \gamma, \lambda$. Journal of Antibiotics 41, 519-529.

CoX, K. L. \& SENO, E. T. (1990). Maintenance of cloned biosynthetic genes in Streptomyces fradiae on freely-replicating and integrative plasmid vectors. Journal of Cellular Biochemistry, Supplement 14A, Abstracts of the 14th UCLA Symposia, abstract CC 016, p. 93.

CUNDLIFFE, E. (1978). Mechanism of resistance to thiostrepton in producing-organism Streptomyces azureus. Nature, London 272, 792-795.

Davies, G. \& Green, R. H. (1986). Avermectins and milbemycins. Natural Product Reports 3, 87-121.

Fishman, S. E., Cox, K., Larson, J. L., Reynolds, P. A., Seno, E. T., Yeh, W.-K., van Frank, R. \& Hershberger, L. (1987). Cloning genes for the biosynthesis of a macrolide antibiotic. Proceedings of the National Academy of Sciences of the United States of America 84, 8248-8352.

HopWOOD, D. A., Kieser, T., Wright, H. M. \& BibB, M. J. (1983). Plasmids, recombination and chromosomal mapping in Streptomyces lividans 66. Journal of General Microbiology 129, 2257-2269.

Hopwood, D. A., BibB, M. J., Chater, K. F., Kieser, T., Bruton, C. J., Kieser, H. M., Lydiate, D. J., SMith, C. P., WARD, J. M. \& SCHREMPF, H. (1985a). Genetic Manipulation of Streptomyces: a Laboratory Manual. Norwich, UK: John Innes Foundation.

Hopwood, D. A., Malpartida, F., Kieser, H. M., IKeDa, H., Duncan, J., Fuin, I., Rudd, B. A. M., Floss, H. G. \& OMUra, S.
$(1985 b)$. Production of hybrid antibiotics by genetic engineering. Nature, London 314, 642-645.

HUNTER, I. S. \& BAUMBERG, S. (1989). Molecular genetics of antibiotic formation. Symposia of the Society for General Microbiology 44, $121-162$.

JoNES, G. H. \& HopwoOD, D. A. (1984). Molecular cloning and expression of the phenoxazinone synthase gene from Streptomyces antibioticus. Journal of Biological Biochemistry 259, 14151-14157.

Katz, E., Thompson, C. J. \& Hopwood, D. A. (1983). Cloning and expression of the tyrosinase gene from Streptomyces antibioticus in Streptomyces lividans. Journal of General Microbiology 129, 2703-2714.

Kendall, K. J. \& CohEN, S. N. (1988). Complete nucleotide sequence of the Streptomyces lividans plasmid pIJ101 and correlation of the sequence with genetic properties. Journal of Bacteriology 170, 4634-4651.

Kieser, T., HopwoOd, D. A., Wright, H. M. \& Thompson, C. J. (1982). pIJ101, a multi-copy broad host range Streptomyces plasmid: functional analysis and development of DNA cloning vectors. Molecular and General Genetics 185, 223-238.

Lydiate, D. J., Malpartida, F. \& Hopwood, D. A. (1985). The Streptomyces plasmid SCP2*: its functional analysis and development into useful cloning vectors. Gene 35, 223-235.

Malpartida, F. \& HopWOOd, D. A. (1984). Molecular cloning of the whole biosynthetic pathway of a Streptomyces antibiotic and its expression into a heterologous host. Nature, London 309, 462-464.

Murakami, T., Holt, T. G. \& Thompson, C. J. (1989). Thiostreptoninduced gene expression in Streptomyces lividans. Journal of Bacteriology 171, 1459-1466.

OMURa, S., IKeda, H., Malpartida, F., Kieser, H. M. \& HopwoOd, D. A. (1986). Production of new hybrid antibiotics Mederrhodin A and B by a genetically engineered strain. Antimicrobial Agents and Chemotheraphy 29, 13-19.

ONISHI, J. C. \& MiLLER, T. W. (1985). The lack of antifungal activity by avermectin $B_{1 a}$. Journal of Antibiotics 38, 1568-1572.

Ono, M., Mishima, H., Takiguchi, Y. \& Terao, M. (1983) Milbemycins; a new family of macrolide antibiotics. Studies on the biosynthesis of milbemycins $\alpha_{2}, \alpha_{4}$ and $\mathrm{D}$ using ${ }^{13} \mathrm{C}$ labelled precursors. Journal of Antibiotics 36, 991-1000.

PIRET, J. M. \& Chater, K. F. (1985). Phage mediated cloning of bldA, a region involved in Streptomyces coelicolor morphological development, and its analysis by genetic complementation. Journal of Bacteriology 163, 965-982.

Ramsay, M. V. J., Roberts, S. M., Russell, J. C., Shingler, A. H., Slawin, A. M. Z., Sutherland, D. R., Tiley, E. P. \& Williams, D. J. (1987). Novel antiparasitic agents by modification of a new natural product series. Tetrahedron Letters 28, 5353-5356.

Rudd, B. A. M., Noble, D., Foster, G., LANe, S. J. \& Webb, G. (1990). The biosynthesis of a family of novel antiparasitic macrolides. In Abstracts of the 6th International Symposia of the Genetics of Industrial Microorganisms, Strasbourg, abstract A70, p. 96.

SAMBrooK, J., Fritsch, E. F. \& Maniatis, T. (1989). Molecular Cloning. A Laboratory Manual, 2nd edn. Cold Spring Harbor, New York: Cold Spring Harbor Laboratory.

Thompson, C. J., Kieser, T., WARD, J. M. \& Hopwood, D. A. (1982a). Cloning of antibiotic resistance and nutritional genes in streptomycetes. Journal of Bacteriology 151, 668-677.

Thompson, C. J., Skinner, R. H., Thompson, J., Ward, J. M., HoPWOOD, D. A. \& CUNDLIFFE, E. $(1982 b)$. Biochemical characterisation of resistance determinants cloned from antibiotic-producing streptomycetes. Journal of Bacteriology 151, 678-685.

VALliNS, W. J. S. \& BAUMBERG, S. (1985). Cloning of a DNA fragment from Streptomyces griseus which directs streptomycin phosphotransferase activity. Journal of General Microbiology 131, 1657-1669.

Ward, J. B., Noble, H. M., Porter, N., Fletton, R. A. \& Noble, D. (1984). Antiparasitic compounds and their preparation. UK Patent GB2, 166, 436A, May 8, 1986.

White, A. T., Newland, H. S., Taylor, H. R., Erttmann, K. D., Keyvan-Larijani, E., Nara, A. Aziz, S., D'AnNa, S. A., Williams, P. N. \& GREENE, B. M. (1987). Controlled trial and dose-finding study of Ivermectin for treatment of onchocerciasis. Journal of Infectious Diseases 156, 463-470. 